\title{
Antioxidant, antidiabetic, anti-inflammatory and anticancer potential of some seaweed extracts
}

\author{
Shimaa EL SHAFAY ${ }^{1}$, Mostafa EL-SHEEKH ${ }^{1 *}$ (D), Eman BASES ${ }^{1}$, Rania EL-SHENODY ${ }^{1}$
}

\begin{abstract}
This study aims to evaluate the secondary metabolites, cytotoxicity, antioxidant, antidiabetic, anti-inflammatory, and anticancer activities of four selected seaweeds Padina pavonica, Taonia atomaria, Jania rubens, and Corallina elongata. The maximum value of phenolic content $(176.7 \pm 6.9 \mathrm{mg}$ gallic acid equivalents/g crude extract) and tannin content $(26.5 \pm 4.3 \mathrm{mg}$ tannic acid equivalents/g crude extract), was shown in the methanol extract of $J$. rubens and P. pavonica, respectively. While the ethanol extract of T. atomaria recorded the highest values of total flavonoid content ( $374.1 \pm 27.4 \mathrm{mg}$ quercetin equivalents/g crude extract) and total saponins content ( $30.2 \pm 0.7 \mathrm{mg}$ cholesterol equivalents/g crude extract, respectively) compared to other seaweeds. Methanol extract of J. rubens and C. elongata exhibited the greatest content of alkaloids ( $25.8 \pm 4.4$ and $22.7 \pm 2.6 \mathrm{mg} / \mathrm{g} \mathrm{d}$ wt.). The methanol extract of $P$. pavonica established the highest DPPH radical scavenging activity $(55.7 \% \pm 0.1)$ at $50 \mu \mathrm{g} / \mathrm{mL}$. Among the selected seaweed extracts, the ethanol extract of $T$. atomaria demonstrated the maximum a-amylase inhibition capacity $(66.3 \% \pm 0.0)$. Methanol extract of $J$. rubens and P. pavonica species effectively prevented the hypotonicity-induced haemolysis in a concentration-dependent manner compared with the diclofenac potassium as a standard anti-inflammatory drug. In vitro, the reported results also supported the safety and non-toxicity of the four seaweed extracts on WI-38 cell line at lower concentrations. J. rubens and P. pavonica methanol extracts recorded the highest cell growth inhibition of the HeLa Cancer Cell Lines compared to other seaweed extracts and the standard drug Cisplatin.
\end{abstract}

Keywords: seaweeds; secondary metabolites; antioxidant; antidiabetic; anti-inflammatory; cytotoxicity; anticancer.

Practical Application: The search for new natural resources has proven to be healthy, economical, and environmentally friendly, like seaweeds applied as food, as antioxidants, antidiabetic, anti-inflammatory, and anticancer agents.

\section{Introduction}

In living organisms, ROS (reactive oxygen species) are generated during the metabolism and induced oxidative damage (Santos-Sánchez et al., 2019). Different chronic diseases, as cancer, atherosclerosis, diabetes, and aging, can be caused by the oxidative stress impact of the ROS on biomolecules such as lipids, proteins, and nucleic acids (Pirian et al., 2017). Antioxidants can inhibit the negative impacts of oxidative damage (Adwas et al., 2019; El-Sheekh et al., 2020).

Diabetes mellitus (DM) is a category of metabolic disturbance defined by an irregular increase in plasma glucose rates due to unbalanced production of insulin and/or insensitivity to the effect of this hormone in cellular receptor signal transduction (Stojkovic et al., 2019). There are two major types of Diabetes mellitus (DM), type 1 and type 2. Type 2 represents nearly $90 \%$ of all diabetes cases, which is distinguished by a varying degree of insulin resistance and/or insufficient insulin production in cells (Lee et al., 2009).

Cancer is one of the most significant ailments worldwide, and the best standard of treatment is cancer chemotherapy. The majority of the anticancer medications utilized in chemotherapy are cytotoxic to normal cells (Zandi et al., 2010).
Inflammation is a reaction of living tissues towards damage, which involves systemic response and local responses (Hardmann et al., 1998). Seaweeds are marine, photosynthetic algae abounding in all oceans. Three main seaweed phyla are identified: Chlorophyta, Rhodophyta, and Phaeophyta (Shannon \& Abu-Ghannam, 2019). Strong antioxidant activities were detected with seaweed extracts (Al-Araby et al., 2020; El-Sheekh et al., 2020). Seaweeds are recognized as a gorgeous origin of natural and bioactive compounds such as polyphenols, vitamins, polysaccharides, peptides, and fatty acids with various functional properties and structures that supply the living organisms with various health benefits (Ganesan et al., 2008; Hayes 2015; Okolie et al., 2018). Furthermore, green, red, and brown algae have compounds with antioxidants (Vega et al., 2020), anti-inflammatory (Yu et al., 2019), antidiabetic (Jia et al., 2020), and anticancer activities (El-Shaibany et al., 2020).

Novel natural antioxidants in the diets of animals and humans, such as seaweeds, are the current research needs. The purpose of this study is to estimate the content of secondary metabolites of four seaweeds J. rubens, C. elongata, T. atomaria, and P. pavonica, which are collected from Rocky Bay of Abu Qir in Alexandria, Egypt. The pharmaceutical, medicinal and nutritional applications of the tested seaweeds were documented by assessing 
the cytotoxicity, antioxidant, antidiabetic, anti-inflammatory, and anticancer effects of these seaweed extracts.

\section{Materials and methods}

\subsection{Seaweeds collection}

Padina pavonica, Taonia atomaria, Jania rubens, and Corallina elongata have been collected from Rocky Bay of Abu Qir in Alexandria, Egypt. The collected seaweeds were carefully washed with seawater, then tap water. They were brought to the laboratory in iced condition. The seaweeds were air-dried in the shade at room temperature and then in the oven at $38 \pm 2{ }^{\circ} \mathrm{C}$. The dried samples were ground to a fine powder and preserved in strongly closed containers for further investigations. The seaweeds were identified according to Aleem (1993), Jha et al. (2009) and Kanaan \& Belous (2016), then using the Algae Base website to confirm their identification (Guiry \& Guiry, 2019).

\subsection{Preparation of seaweeds extracts (conventional method)}

The extraction was performed with several solvents (methanol, ethanol, hexane, diethylether, aqueous cold, aqueous hot) by steeping the material in the corresponding solvents $(1: 30 \mathrm{w} / \mathrm{v})$ within a conical flask then closed with cotton wool. Next, retained on a rotatory shaker at $120 \mathrm{rpm}$ at $20-30^{\circ} \mathrm{C}$ for 2 days. The extracts were filtered and the filtrate put in the oven at $45^{\circ} \mathrm{C}$ to get rid of the solvent. The crude extracts were suspended in the corresponding solvents to obtain a final concentration of $5 \mathrm{mg} / \mathrm{mL}$ then kept at $-20^{\circ} \mathrm{C}$ in an airtight container to control the microbial contamination.

The best algae with the best solvent were selected depending on the antioxidant assays evaluated in the previously published work (El-Sheekh et al., 2020). The following extracts were observed to have the highest antioxidant potential; the methanol extract of $P$. pavonica, the methanol extract of $J$. rubens, the ethanol extract of T. atomaria, and the methanol extract of C. elongata

\subsection{Estimation of secondary metabolites}

\section{Total phenolic content}

The total phenolic content was demonstrated according to the method of Taga et al. (1984). Folin-Ciocalteu reagents $(100 \mu \mathrm{L}, 50 \% \mathrm{v} / \mathrm{v})$ were added to sodium carbonate $(2 \mathrm{~mL}, 2 \%$ $\mathrm{w} / \mathrm{v})$ then were mixed well with the extract of seaweeds $(100 \mu \mathrm{L})$. This was followed by incubation at room temperature for $30 \mathrm{~min}$, and then the absorbance of the blue color solution was assessed at $750 \mathrm{~nm}$ against a blank (100 $\mu \mathrm{L}$ solvent was used instead of algal extract). The standard curve was done using various concentrations of gallic acid. The total phenolic content was expressed as $\mathrm{mg} / \mathrm{g}$ crude extract.

\section{Total flavonoid content}

For flavonoids estimation, an aluminum chloride colorimetric assay was performed (Chang et al., 2002). Algal extract was mixed with ethanol $(95 \%, 0.5 \mathrm{~mL})$, aluminum chloride $(0.1 \mathrm{~mL}$, $10 \%)$, potassium acetate $(0.1 \mathrm{~mL}, 1 \mathrm{M})$ and distilled-deionized water $(2.8 \mathrm{~mL})$. The mixture was incubated for $30 \mathrm{~min}$ at room temperature, and then the absorbance was detected at $415 \mathrm{~nm}$. An amount of aluminum chloride (10\%) was used with the same amount of distilled-deionized water for blank samples. The calibration curve was performed using quercetin as a standard flavonoid. The total content of flavonoid was described as $\mathrm{mg} / \mathrm{g}$ crude extract.

\section{Total saponin content}

Saponins were evaluated quantitatively by the method shown by Hiai et al. (1975). An aliquot $(0.5 \mathrm{~mL})$ of the algal extract was mixed with $0.5 \mathrm{~mL}$ of $8 \%$ vanillin in ethanol. The reaction mixture was placed in an ice bath, and $5 \mathrm{~mL}$ of $72 \%$ sulfuric acid was added and then heated for 10 minutes at $60^{\circ} \mathrm{C}$ in a water bath. The reaction mixture was cooled in the ice-cold water bath, and the absorbance was estimated at $544 \mathrm{~nm}$. For the blank sample, $0.5 \mathrm{~mL}$ solvent was used instead of algal extract. Cholesterol was used as standard saponins for plotting the standard curve, and the content of saponins was expressed as $\mathrm{mg} / \mathrm{g}$ crude extract.

\section{Total tannin content}

The total tannin content was assessed in accordance with the method described by European Community (2000). Two hundred microliters of the extract were added to $1 \mathrm{~mL}$ of distilled-deionized water, $200 \mu \mathrm{L}$ of ferric ammonium citrate $(3.5 \mathrm{~g} / \mathrm{L})$ freshly prepared, and $200 \mu \mathrm{L}$ of ammoniac (20\%). The absorbance was estimated at $525 \mathrm{~nm}$ after $10 \mathrm{~min}$ of the incubation period. For the blank sample, $200 \mu \mathrm{L}$ solvent was used rather than the algal extract. The standard curve was measured using tannic acid, and the results were expressed as $\mathrm{mg} / \mathrm{g}$ crude extract.

\section{Total alkaloid content}

Total alkaloids were developed quantitatively according to (Harbone 1973; Harborne, 1984). One gram of the algal extract was mixed with $70 \%$ ethanol and glacial acetic acid (4: 1 ). The reaction mixture was allowed to stand for 6 hours at least and then was filtered. By a drop-wise adding of concentrated ammonia solution, alkaloids in the supernatant were precipitated. The precipitated alkaloids were filtered on a pre-weighed filter paper (Whatman No.1) and then dried in an oven at $70{ }^{\circ} \mathrm{C}$ to a constant weight. The content of alkaloids was measured and expressed as $\mathrm{mg} / \mathrm{g}$ dry. wt. of the seaweed samples.

\subsection{Estimation of antioxidant activities (DPPH radical scavenging activity)}

Bleaching the purple-colored solution of 1,1- diphenyl-2picrylhydrazyl radical (DPPH) is determined by the electron donation potential of the seaweed extracts and the scavenging activities of the extracts were evaluated as stated by the method of (Yen \& Chen, 1995) with some modifications. Two milliliters $\mathrm{mL}$ of DPPH solution $\left(0.03 \mathrm{~g} \mathrm{l}^{-1}\right.$ in methanol) were mixed with $2.0 \mathrm{~mL}$ of different concentrations of tested seaweeds extracts $(10: 50 \mu \mathrm{g} / \mathrm{mL})$. The reaction mixture was vortexed for $1 \mathrm{~min}$ and was incubated at room temperature 
for one hour in the dark, then its absorbance was detected at $517 \mathrm{~nm}$. The scavenging effect (\%) was calculated as the following Equation 1:

DPPH radical scavenging activity $\%=\left(A_{\text {Control }}-A_{\text {Sample }} / A_{\text {Control }}\right) \times 100$

where $\mathrm{A}_{\text {ControL }}$ is the absorbance of the control reaction $(2.0 \mathrm{~mL}$ of a DPPH radical solution) and $\mathrm{A}_{\text {Sample }}$ is the absorbance in the presence of algal extract.

The half-maximal inhibitory concentration $\left(\mathrm{IC}_{50}\right)$ values were also calculated using Microsoft Excel

\subsection{Antidiabetic activity ( $\alpha$-amylase activity inhibition)}

Alpha-amylase activity inhibition was assessed by estimating changes in 3.5-dinitrosalicylate acid into nitro-aminosalicylate acid catalyzed by a-amylase by spectrophotometry (Apostolidis et al., 2011). $250 \mu \mathrm{L}$ of tested seaweed extracts and $250 \mu \mathrm{L}$ of $0.02 \mathrm{M}$ sodium phosphate buffer ( $\mathrm{pH} 6.9$ with $0.006 \mathrm{M} \mathrm{NaCl}$ ) containing $0.5 \mathrm{mg} / \mathrm{mL}$ of $\alpha$-amylase, and then incubated at $25{ }^{\circ} \mathrm{C}$ for $10 \mathrm{~min}$. After pre-incubation, add $250 \mu \mathrm{L}$ of $1 \%$ soluble starch in $0.02 \mathrm{M}$ sodium phosphate buffer ( $\mathrm{pH} 6.9$ with $0.006 \mathrm{M} \mathrm{NaCl}$ ) and incubated at $25^{\circ} \mathrm{C}$ for $10 \mathrm{~min}$. The reaction was stopped by the addition of $500 \mu \mathrm{L}$ of 3,5-dinitrosalicylate acid (DNS) (96 mM) color reagent (Sigma, St. Louis, USA) and incubated in boiling water for $5 \mathrm{~min}$, then cooled at room temperature. The absorbance of the reaction was measured at a wavelength of $540 \mathrm{~nm}$. Absorbance values were used to calculate the inhibition activity of the enzyme as follows Equation 2:

$\alpha$ - amylase activity inhibition $\%=$ Absorbance control -

(Absorbance sample with enzyme - Absorbance sample without enzyme)/

Absorbance control X 100

\subsection{In vitro anti-inflammatory activities (membrane stabilization assay)}

\section{Preparation of Red Blood Cells (RBCs) suspension}

RBCs suspension was prepared according to Sadique et al. (1989) and Sakat et al. (2010). The blood was obtained from a healthy human volunteer who did not take any NSAIDs (Non-Steroidal Anti-Inflammatory Drugs) for 2 weeks before the experiment and transported to the centrifuge tubes containing EDTA. The tubes were centrifuged for $10 \mathrm{~min}$ at $3000 \mathrm{rpm}$ and then were washed three times with an equal volume of normal saline $(0.85 \%$ sodium chloride). The blood volume was calculated and reconstituted as $10 \% \mathrm{v} / \mathrm{v}$ suspension with normal saline (10\% stock solutions were performed by mixing $1 \mathrm{~mL}$ RBCs suspension with $9 \mathrm{~mL}$ distilled water).

\section{Hypotonicity-induced haemolysis}

Hypotonicity-induced haemolysis was estimated according to the method of (Azeem et al., 2010). Briefly, $0.5 \mathrm{~mL}$ of different concentrations of the tested seaweed extracts $(10: 50 \mu \mathrm{g} / \mathrm{mL})$ was added to $1 \mathrm{~mL}$ of phosphate buffer ( $\mathrm{pH} 7.4$ ), $2 \mathrm{~mL}$ of hyposaline ( $0.36 \%$ Sodium chloride), and $0.5 \mathrm{~mL}$ of $10 \%$ RBCs suspension. Diclofenac potassium $(100 \mu \mathrm{g} / \mathrm{mL})$ was used as a standard drug and control (distilled water instead of hyposaline to produce $100 \%$ hemolysis). The mixture was kept for 30 minutes at $37^{\circ} \mathrm{C}$ then centrifuged at $3000 \mathrm{rpm}$. The supernatant absorbance was measured by a spectrophotometer at $560 \mathrm{~nm}$ to determine the haemoglobin content.

Haemolysis percentage inhibition was calculated as follows (Equation 3):

Haemolysis percentage inhibition $\%=$

(Absorbance control-Absorbance sample)/

Absorbance control $\times 100$

The concentrations of the tested extracts that lead to $50 \%$ inhibition of the haemolysis (IC50) were determined by Microsoft Excel.

\subsection{Cytotoxicity (MTT) assay}

This technique was evaluated using the method of (Kohler et al., 2005). WI-38 human Caucasian fibroblast-like fetal lung cell line (normal cell lines) and Human Cervical Hela Cancer Cell Lines were kept in a standard medium containing DMEM (Dulbecco's Modified Eagle Medium) with fetal bovine serum $(10 \% \mathrm{v} / \mathrm{v})$ and penicillin/streptomycin $(1 \% \mathrm{v} / \mathrm{v})$ and kept at $37{ }^{\circ} \mathrm{C}$ in a $5 \% \mathrm{CO} 2$ before to use. After $24 \mathrm{~h}$ the cells were treated with different concentrations ( 10 to $1000 \mu \mathrm{g} / \mathrm{mL}$ ) of the four selected seaweed extracts. The medium was take off after $24 \mathrm{~h}$ and $48 \mathrm{~h}$ of the incubation period, and replaced by $5 \mathrm{mg} / \mathrm{mL}$ of MTT reagent to each well, and then re-incubated for 3-4 h. The formed formazan crystals were dissolved in $100 \mu \mathrm{L}$ acidified isopropanol and estimated at $630 \mathrm{~nm}$ using ELISA microplate reader (Bio-Rad microplate reader, Japan). DMSO was used as a positive control. Repeated each concentration in triplicates, and cell viability was calculated by the following Equation 4:

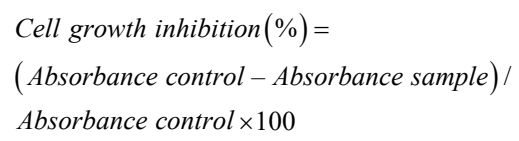

The IC50 values were calculated using Microsoft Excel.

\subsection{Statistical analysis}

All the assays were repeated in triplicate, and the means \pm standard deviation (SD) were recorded. The statistically significant difference between the secondary metabolites of seaweeds was identified by the analysis of variance (One-way ANOVA) followed by Duncan's multiple range test for data with significant differences, at $p<0.05$, using the SPSS 23.0 software. The cytotoxicity and anticancer activities of seaweed extracts were compared using one-way ANOVA and post hoc Tukey HSD's test using the SPSS 23.0 software, significant values at $p<0.05$. 


\section{Results and discussion}

\subsection{Estimation of secondary metabolites: quantitative phytochemical analysis}

Antioxidants from natural sources are not restricted to terrestrial sources, and studies showed that seaweeds are also abundant with natural antioxidant substances (Duan et al., 2006; Kuda et al., 2007), including phenolics, flavonoids, saponins, tannins, and alkaloids. Such antioxidants help to cure numerous serious diseases such as aging diseases, cardiovascular diseases, and cancer through scavenging free radicals (Kohen \& Nyska, 2002). Currently, the discovery of natural antioxidants mainly is increasingly concerned as bioactive phytochemicals, that are largely more safe than synthetic analogies, in addition to their protective role in improving diseases like Alzheimer's and aging diseases, diabetes, cancer, arthritis, and atherosclerosis (Santos-Sánchez et al., 2019).

In the current study, quantitative phytochemical analyses were estimated. The collected seaweeds displayed a considerable content of phenolics, flavonoids, saponins, tannins, and alkaloids significantly different at $P \leq 0.05$ (Table 1 ). A variety of terrestrial and marine plants contain phenolics, which are sometimes mentioned as polyphenolic compounds. Due to their antioxidant capacity, they are utilized in animal and human diets. Up till now, most phenolics extracted from marine origins are from macroalgal sources (Li et al., 2011). Phenolics found in marine algae with a variety of biological activities such as antioxidant properties (Duan et al., 2006; Kuda et al., 2007). Furthermore, they were recorded to show therapeutic and medicinal properties as anti-inflammatory, antitumor, anticarcinogenic, antimicrobial, antiviral activities, and impacts on neurodegenerative diseases (Oueslati et al., 2012).

In phenolics, the maximum value was recorded for the methanol extract of $J$. rubens $(176.7 \pm 6.9 \mathrm{mg}$ gallic acid equivalents/g crude extract). While the minimum value was shown with the methanol extract of C. elongata $(92.9 \pm 3.8 \mathrm{mg}$ gallic acid equivalents/g crude extract) (Table1). This was in line with Dang et al. (2018), who showed that the great total phenolic content levels were detected in the seaweed extracts of Sargassum Linearifolium, Sargassum vestitum, Sargassum podocanthum, Phyllospora comosa, Hormosira banksii, and
Padina sp (48.13-158.82 mg GAE g $^{-1}$ extract). The use of different species has led to differences in the extracted phenolic compounds (Cho et al., 2010).

As shown in Table 1, the total flavonoid content of algal extracts recorded the highest value with the ethanol extract of T.atomaria $(374.1 \pm 27.4 \mathrm{mg}$ quercetin equivalents/g crude extract). However, the lowest value was detected with the methanol extract of $J$. rubens $(173.7 \pm 6.8 \mathrm{mg}$ quercetin equivalents/g crude extract) and the methanol extract of C. elongata $(69.7 \pm 2.5 \mathrm{mg}$ quercetin equivalents/g crude extract). In the present work, the brown algae gave the maximum total flavonoid contents, and these results were in line with El-Shenody et al. (2019), who confirmed that the brown algae (Dictyota dichotoma and Turbinaria decurrens) recorded higher total flavonoid contents than the red algae (Laurencia obtusa). Moreover, It has been reported that flavonoids have antioxidant potential, scavenges of a wide range of ROS, inhibit lipid peroxidation, and have potential pharmacological activities against a great range of diseases (Ross \& Kasum, 2002; Williams et al., 2004).

Seaweeds are the source of important metabolites that have beneficial effects on health. Saponins are one of the most important and useful metabolites of marine macroalgae. Saponins have various applications in the cosmetic, food industry, and health section. In living organisms, seaweed saponins prevent or reduce many diseases due to their biological and physicochemical features (Feroz, 2018). Total saponins content has been investigated as shown in Table 1 . The ethanol extract of $T$. atomaria and methanol extract of $J$. rubens recorded the highest value $(30.2 \pm 0.7$ and $19.9 \pm 2.1 \mathrm{mg}$ cholesterol equivalents/g crude extract, respectively), while the methanol extract of $P$. pavonica and C.elongata showed the lowest value $(15.3 \pm 0.1$ and $11.5 \pm 0.4 \mathrm{mg}$ cholesterol equivalents/g crude extract, respectively). Previous studies reported great saponins in the methanol and acetone extracts of brown algae Turbinaria ornata (Rajkumar \& Bhavan, 2017).

As it is clear from (Table 1), the methanol extract of $P$. Pavonica recorded the highest total tannin content (26.5 \pm $4.3 \mathrm{mg}$ tannic acid equivalents/g crude extract), and this was consistent with (Fauzi et al., 2018), who stated that Padina $s p$ contains a greater total tannin content than Sargassum sp. The tannins present in plants can treat internal oral diseases,

Table 1. Phenolics, Flavonoids, Saponins, Tannins, and Alkaloids in the algal species collected from Abu Qir Bay, Alexandria, Egypt.

\begin{tabular}{|c|c|c|c|c|c|}
\hline \multirow[b]{2}{*}{ Seaweeds } & \multirow[b]{2}{*}{$\begin{array}{c}\text { Phenolics } \\
\text { (mg gallic acid } \\
\text { equivalents/g crude } \\
\text { extract) }\end{array}$} & \multirow[b]{2}{*}{$\begin{array}{c}\text { Flavonoids } \\
\text { (mg quercetin } \\
\text { equivalents/g crude } \\
\text { extract) }\end{array}$} & \multicolumn{3}{|c|}{ Secondary metabolites } \\
\hline & & & $\begin{array}{c}\text { Saponins } \\
\text { (mg Cholesterol } \\
\text { equivalents/g crude } \\
\text { extract) }\end{array}$ & $\begin{array}{c}\text { Tannins } \\
\text { (mg tannic acid } \\
\text { equivalents/g crude } \\
\text { extract) }\end{array}$ & $\begin{array}{c}\text { Alkaloids } \\
(\mathrm{mg} / \mathrm{g} \text { DW })\end{array}$ \\
\hline P. pavonica (methanol extract) & $152.5 \pm 8.8^{b}$ & $206.7 \pm 4.7^{b}$ & $15.3 \pm 0.1^{\mathrm{c}}$ & $26.5 \pm 4.3^{\mathrm{a}}$ & $7.8 \pm 0.61^{b}$ \\
\hline J. rubens (methanol extract) & $176.7 \pm 6.9^{\mathrm{a}}$ & $173.7 \pm 6.8^{c}$ & $19.9 \pm 2.1^{b}$ & $4.5 \pm 1.3^{\mathrm{b}}$ & $25.8 \pm 4.4^{\mathrm{a}}$ \\
\hline T. atomaria (ethanol extract) & $157.3 \pm 5.9^{b}$ & $374.1 \pm 27.4^{\mathrm{a}}$ & $30.2 \pm 0.7^{\mathrm{a}}$ & $2.9 \pm 0.8^{\mathrm{b}}$ & $8.5 \pm 0.09^{b}$ \\
\hline C. elongata (methanol extract) & $92.9 \pm 3.8^{c}$ & $69.7 \pm 2.5^{\mathrm{d}}$ & $11.5 \pm 0.4^{\mathrm{d}}$ & $0.4 \pm 0.1^{\mathrm{b}}$ & $22.7 \pm 2.6^{\mathrm{a}}$ \\
\hline F value & 89.98 & 230.52 & 160.72 & 84.43 & 41 \\
\hline$P$ value & 0.001 & 0.001 & 0.001 & 0.001 & 0.001 \\
\hline
\end{tabular}

Data are expressed as the mean \pm standard deviation (SD) of three replicates. DW: Dry Weight of seaweeds. Different letters represent the statistical comparisons between groups using one-way ANOVA and post hoc Duncan's test $(\mathrm{p}<0.05)$. 
including brown seaweeds screened for having tannins (Qasem, 2015). However, in the present study, the lowest tannin content was observed with methanol extract of J. rubens, ethanol extract of T.atomaria, methanol extract of C. elongata $(4.5 \pm 1.3,2.9 \pm$ 0.8 , and $0.4 \pm 0.1 \mathrm{mg}$ tannic acid equivalents/g crude extract, respectively) as recorded in the red alga, Jania rubens, Corallina mediterranea and Pterocladia capillacea (Mohy El-Din \& ElAhwany, 2016), brown algae, Dictyota dichotoma (Deyab et al., 2016).

Alkaloids are heterocyclic nitrogen compounds, which naturally exist in marine organisms, plants, animals, and microbes. While alkaloids were widely studied in plants, few findings in marine algae are stated since marine algal alkaloids are relatively rare compared to terrestrial plant alkaloids (Güven et al., 2010). Changes in alkaloid content in the different seaweeds were observed during the present study (Table 1). The highest alkaloid content in the collected seaweeds was shown with the methanol extract of J. rubens and C.elongata ( $25.8 \pm 4.4$ and $22.7 \pm 2.6 \mathrm{mg} / \mathrm{g} \mathrm{d} \mathrm{wt}$.), respectively. Otherwise, the ethanol extract of T.atomaria and the methanol extract of P.pavonica recorded the lowest alkaloid content $(8.5 \pm 0.09$ and $7.8 \pm 0.61 \mathrm{mg} / \mathrm{g} \mathrm{d}$ wt. $)$. Alkaloids in red seaweeds were remarkable in the current study, and these observations were in harmony with (Kumbhar et al., 2014), who mentioned that alkaloids were higher in the red species of seaweeds than brown species.

Previous findings showed that variations in the phytochemical contents of algae rely on the environmental nutrient content (Mohamed et al., 2012), geography and season (Stirk et al., 2007), temperature and photoperiod (Zucchi \& Necchi, 2001),
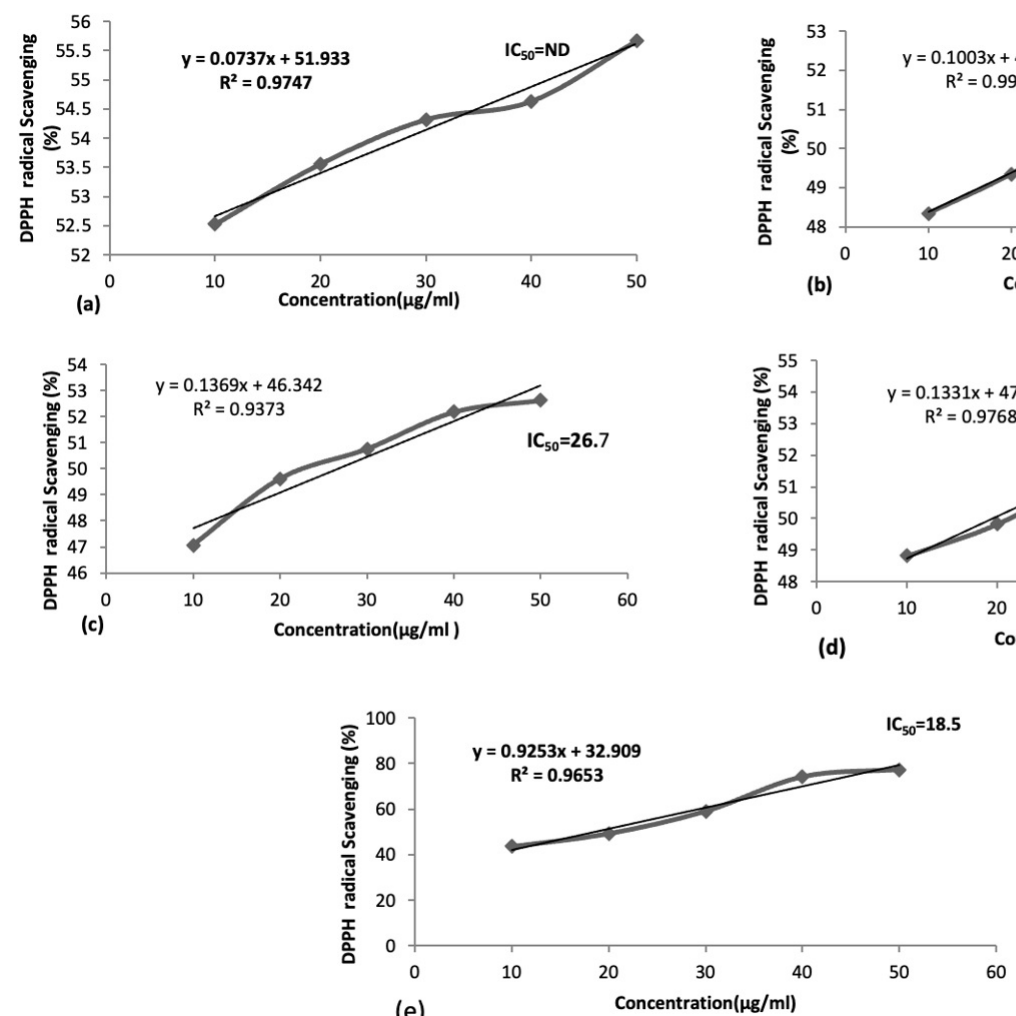

(e)

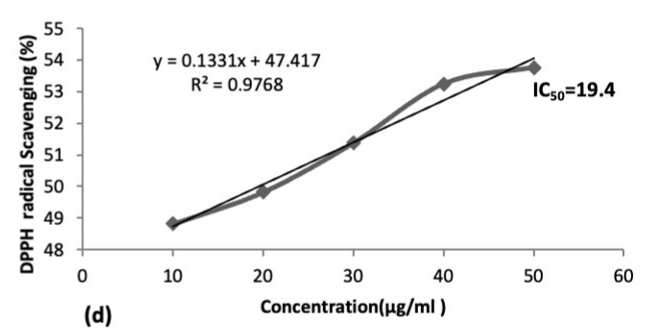
icrylhydrazyl radical) is a steady free radical and showing the highest absorbance at $517 \mathrm{~nm}$. Antioxidants will combine this electron with a donation of hydrogen that induces a shift of color from purple to yellow, and the subsequent discoloration is stoichiometric in terms of the electrons number consumed (Ananthi et al., 2010).

DPPH is a compound that has a nitrogen-free radical, and free radical scavengers can easily destroy it (Chew et al., 2008). The antioxidative compounds ability that acts as hydrogen donors can be tested by the DPPH assay (Singh \& Rajini, 2004). The antioxidant capacity of the tested seaweeds with different solvents was observed via their DPPH radical scavenging ability. All the studied macroalgal extracts have reduced the stable DPPH radical to the yellow-colored 1,1- diphenyl-2-picrylhydrazyl radical based on the species and solvent. Concerning the antioxidant activity evaluated by DPPH method and expressed as percentage and IC50, which is the concentration of extract that requires scavenging of $50 \%$ of the $\mathrm{DPPH}$ radical. The lowest $\mathrm{IC}_{50}$ identifies the strongest level of antioxidant activity. The result in Figure 1

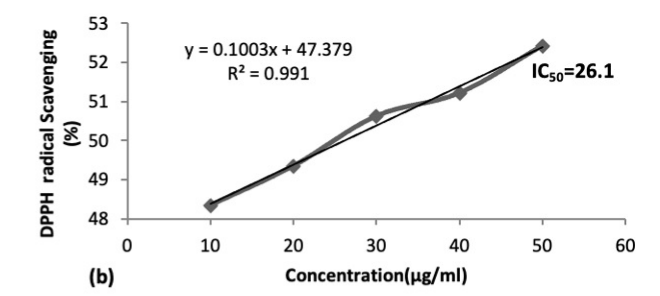

as well as the quality and density of light. Therapeutically, tannins have been used as antiulcer, antibacterial, antiviral, and antioxidant agents. Lots of tannins containing drugs are used

\subsection{In vitro antioxidant activity}

\section{$D P P H$ radical scavenging activity}

Due to its odd electron, DPPH radical (1,1- diphenyl-2the strongest level of antioxidant activity. The result in Figure 1 
recorded the highest DPPH radical scavenging activity with methanol extract of P. pavonica followed by C.elongata, and the $\mathrm{IC}_{50}$ of P. pavonica was not detected as its minimum concentration showed inhibition percentages were more than $50 \%$, while the $\mathrm{IC}_{50}$ of C.elongata was $19.4 \mu \mathrm{g} / \mathrm{mL}$ compared with the standard curve of ascorbic acid which showed the $\mathrm{IC}_{50}$ at $18.4 \mu \mathrm{g} / \mathrm{mL}$.

Furthermore, the ethanol extract of T. atomaria and methanol extract of J. rubens established the lowest DPPH radical scavenging activity with $\mathrm{IC}_{50}(26.7$ and $26.1 \mu \mathrm{g} / \mathrm{mL}$, respectively). The highest DPPH radical scavenging activity was $55.7 \% \pm 0.1,53.8 \% \pm 0.1$, $52.6 \% \pm 0.1$, and $52.4 \% \pm 0.06$ for the methanol extract of P. pavonica, C.elongata, the ethanol extract of T.atomaria and the methanol extract of J. rubens, respectively at $50 \mu \mathrm{g} / \mathrm{mL}$. The antioxidant potential of these collected seaweeds might be owed to their ability to supply the molecule with a hydrogen atom or function as free radical scavengers (Boonchum et al., 2011). In agreement with these results Ismail et al., (2020) recorded the scavenging activity of Padina pavonica water extract against DPPH to be $55.2 \%$. Furthermore, the sterol hydrocarbon fraction of Taonia atomaria showed strong important inhibitory activities at the maximum concentration of $150 \mu \mathrm{g} / \mathrm{mL}$ against the DPPH radical with $43.23 \%$ (Ibrahim et al., 2016). This suggests that the DPPH radical scavenging activity increase by increasing the concentration of the extract.

\subsection{In vitro antidiabetic activity}

\section{In vitro $\alpha$-amylase inhibition activity}

Regulation of postprandial plasma glucose rates is important in the initial treatment of diabetes (Lee et al., 2009). Stimulating and promoting endogenous insulin secretion, inhibiting pancreatic $\alpha$-amylase, and avoiding pancreatic oxidative damage are deemed potential strategies for controlling type 2 diabetes (Pirian et al., 2017;). Currently, several medication therapies, such as oral hypoglycemic agents, insulin, and its analogues, have been utilized to control type 2 diabetes and minimize the probability of complications, but accumulated studies showed that their side effects and toxicity significantly threaten patients 'health (Jia et al., 2020). As a result, there is an urgent need to search for alternate and non-toxic treatment strategies that could overcome such constraints. Macroalgae or seaweeds also may play a key role in the treatment of diabetes (Unnikrishnan et al., 2015).

The inhibitory effects of the studied seaweed extracts were evaluated for the $\alpha$-amylase enzyme. All selected seaweed extracts exhibited significant (at $\mathrm{p} \leq 0.05)$ activity of $\alpha$-amylase inhibition based on the algal species. As shown in Figure 2, the ethanol extract of T. atomaria exhibited the maximum $\alpha$-amylase inhibition capacity of $66.3 \% \pm 0.0$ followed by the methanol extract of J. rubens and C.elongata recording $34.9 \% \pm 1.9$ and $34.9 \% \pm 2.2$, respectively. On the contrary, the methanol extract of P. pavonica had the lowest $\alpha$-amylase inhibition potential, recording $22.2 \%$ \pm 3.6. Moreover, the percentage inhibition indicated that the ethanol extract of T.atomaria was a significant inhibitor for carbohydrate analyzing $\alpha$-amylase enzymes and thus played a crucial role in regulating postprandial hyperglycemia. It has also been reported that there is a range of beneficial bioactivities as antidiabetic when the diet includes edible brown seaweed.

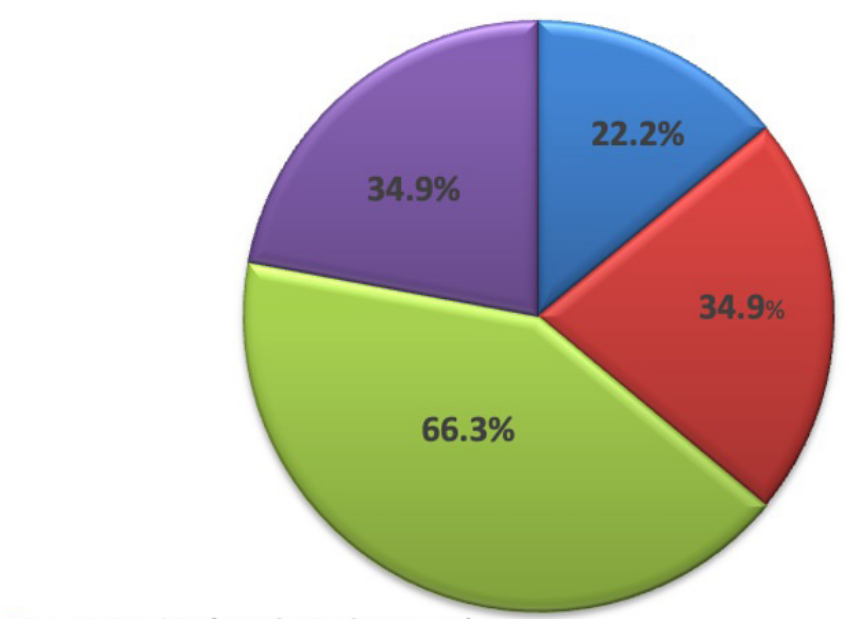

\section{口. pavonica (Methanol extract)}

\section{J. rubens (Methanol extract)}

T.atomaria (Ehanol extract)

\section{- C. elongata (Methanol extract)}

Figure 2. In vitro a amylase inhibitory activity (\%) of total extract of four seaweeds (concentration of extracts used $=5 \mathrm{mg} / \mathrm{mL}$ ).

Wang et al. (2018) stated that the seaweed has nutrients, for example, dietary fibers, vitamins, proteins, and minerals, which could function as antidiabetic agents.

In comparison, several findings have shown the effectiveness of brown and red seaweed extracts such as different Sargassum spp. and Ishige okamurae (Unnikrishnan et al., 2015; Yang et al., 2019), different solvents of Turbinaria decurrens, Padina pavonica and Sargassum muticum (Ismail et al., 2020), as antidiabetic agents and their potent potential as an inhibitor of $\alpha$-amylase.

According to Husni et al. (2016) and Pirian et al. (2017), the antidiabetic potential of marine algae could be attributable to the presence of various phytochemicals such as phenolics, flavonoids, saponins, tannins, and alkaloids which modulate glucose-induced oxidative stress and inhibit starch digestive enzymes by binding to the active sites of the diabetic enzymes and change their catalytic activity, which is also related to the antioxidant activity. The same correlation was shown in this study where the tested seaweeds contained high phenolics, flavonoids, saponins, tannins, and alkaloids content, also they had high antioxidant activity. Antioxidant compounds also play a key role in modulating oxidative stress-related diseases such as cardiovascular diseases, cancer, and diabetes (Wu \& Hansen, 2008). Consequently, a reduction in oxidative stress will inhibit diabetes development (Burton \& Ingold, 1999).

\subsection{In vitro anti-inflammatory activities}

The methanol extract of J. rubens, P. pavonica, C.elongata, and ethanol extract of T.atomaria at concentrations $10-50 \mu \mathrm{g} / \mathrm{mL}$ preserved the human erythrocyte membrane from lysis caused by hypotonic solution. Lysosomes during inflammation liberate 
their enzymes that cause various disorders. The beneficial effects of non-steroidal anti-inflammatory drugs (NSAIDs) were exerted either by preserving the lysosomal membranes or by blocking the liberation of lysosomal enzymes (Mounnissamy et al., 2007). Red blood cell exposure (RBC) to ferocious substances, for example, heat, hypotonic medium, methyl phenylhydrazine, or salicylate, contributes to membrane lysis, followed by haemolysis and haemoglobin oxidation (Ferrali et al., 1992). Considering that the membranes of human red blood cells (HRBC) are identical to components of the lysosomal membrane (Mounnissamy et al., 2007), the inhibition of hypotonicity induced lysis of red blood cell membrane are taken as a test of the anti-inflammatory response mechanism of selected algal extracts. Membrane stabilization reduces serum fluids and protein leakage into the tissues during a phase of increased permeability induced by inflammatory mediators (Chaitanya et al., 2011). Selected algal extracts may be stabilized the membrane of red blood cells by inhibiting the lytic enzymes release and active inflammatory mediators. The hypotonicity-induced haemolysis of erythrocytes is commonly used as a quick, simple, economical, and responsive method in evaluating the anti-inflammatory potential of drugs.

The inhibitory effects of different concentrations of selected algal extracts on the hypotonicity-induced haemolysis of the erythrocyte membrane are shown in Table 2. The algal extracts $(10: 50 \mu \mathrm{g} / \mathrm{mL})$ showed effective inhibition of hypotonicity-induced hemolysis of the erythrocyte membrane in a concentration-dependent manner. The in vitro anti-inflammatory activity of the seaweed extracts was comparable to the diclofenac potassium, which is considered a reference drug $(100 \mu \mathrm{g} / \mathrm{mL})$. In this study, the methanol extract of J. rubens and P. pavonica showed the highest anti-inflammatory activity in a concentration-dependent manner compared with the diclofenac potassium as a standard anti-inflammatory drug. At the same time, the methanol extract of C. elongata and the ethanol extract of T.atomaria recorded the lowest anti-inflammatory activity in all concentrations. Anti-inflammatory activity of the ethyl acetate, methanol, and hexane extracts of the brown seaweed Sargassum wightii in hypotonicity-induced haemolysis was also reported (Pramitha \& Sree Kumari, 2016).

The standard anti-inflammatory drugs and extracts mode of action could be related to the attachment to the erythrocyte membranes and the following change of the cell surface charges
(Rani et al., 2014). It has been stated that certain flavonoids and saponins have in vitro and in vivo a stabilizing effect on the membrane of lysosomes, while saponins and tannins have the potential to bind cations, thus stabilizing the membrane of erythrocyte and other biological macromolecules (Rani et al., 2014; Van Caneghem, 1972). In addition, this stabilizing action of extracts on the membrane of erythrocyte may be attributable to a stabilizing effect of the extract on certain membrane proteins. In this concern, these effects may be owed to the strong occurrence of phytochemical compounds, including phenols, flavonoids, saponins, tannins, and alkaloids in the tested algal extracts.

\subsection{In vitro cytotoxicity of the four seaweed extracts on normal cell line (WI-38 human Caucasian fibroblast-like fetal lung cell line) (MTT assay)}

A major point about bioactive plant compounds is that some of these phytochemicals are toxic to our normal system, so safety is important in producing new drugs (Morobe et al., 2012). In this study, the cytotoxic effect of the methanol extract of P. pavonica, J. rubens, C. elongata, and the ethanol extract of T. atomaria at a concentration ranging from $0-1000 \mu \mathrm{g} / \mathrm{mL}$ was detected on WI-38 normal cell line by using MTT assay. The obtained results also confirmed the safety and non-toxicity of the four seaweed extracts on WI-38 cell line after exposure for 24 hours. The recorded $\mathrm{IC}_{50}$ of seaweed extracts on WI- 38 cell line was above the lower concentrations (10, 50, 100, 200 and $400 \mu \mathrm{g} / \mathrm{mL}$ ), which supports the extracts safety compared to the Cisplatin (chemotherapeutic drug) (Table 3 and 4). This action is in agreement with the observation that no toxicity was detected in all tested concentrations $(0-400 \mu \mathrm{g} / \mathrm{mL})$ of the methanolic and aqueous extract of Padina tetrastromatica on Peripheral blood mononuclear cells (PBMCs) after 48 hours' treatment (Subramaniam et al., 2020). Jania Rubens exhibited a non-effective cytotoxic activity on normal human HCEC (Human Corneal Epithelial Cells) cell line after 72 hours at different concentrations $(0-200 \mu \mathrm{g} / \mathrm{mL})$ (Alghazeer et al., 2016).

\subsection{In vitro cytotoxicity of the four seaweed extracts on human cervical HeLa cancer cell lines (MTT assay)}

The study of the structure elucidation and biological activities of substances derived from marine sources has been a significant issue of research nowadays (Mehdinezhad et al., 2016). Depending

Table 2. Hypotonicity-induced haemolysis (\%) and IC50 of total extract of four seaweeds (concentration of extracts used $=10: 50 \mu \mathrm{g} / \mathrm{mL}$ ).

\begin{tabular}{|c|c|c|c|c|}
\hline \multirow{2}{*}{$\begin{array}{c}\text { Concentrations } \\
(\mu \mathrm{g} / \mathrm{mL})\end{array}$} & \multicolumn{4}{|c|}{ Percentages of inhibition of haemolysis activity (Protection)\% } \\
\hline & P. pavonica (methanol extract) & J. rubens (methanol extract) & T.atomaria (Ethanol extract) & C.elongata (methanol extract) \\
\hline 10 & $58.2 \pm 0.16$ & $65.7 \pm 0.19$ & $41.1 \pm 0.30$ & $42.5 \pm 0.10$ \\
\hline 20 & $66.2 \pm 0.10$ & $69.2 \pm 0.05$ & $43.1 \pm 0.31$ & $54.4 \pm 0.35$ \\
\hline 30 & $72.2 \pm 0.09$ & $74.26 \pm 0.17$ & $48.5 \pm 0.05$ & $56.8 \pm 0.26$ \\
\hline 40 & $74.1 \pm 0.02$ & $78.33 \pm 0.02$ & $53.09 \pm 0.33$ & $62.2 \pm 0.07$ \\
\hline 50 & $77.2 \pm 0.24$ & $79.08 \pm 0.02$ & $57.5 \pm 0.23$ & $66.7 \pm 0.05$ \\
\hline IC50 & ND & ND & 33.13 & 18.34 \\
\hline $\begin{array}{l}\text { Declofenac } \\
\text { potassium } \\
(100 \mu \mathrm{g} / \mathrm{mL})\end{array}$ & \multicolumn{4}{|c|}{$73.2 \pm 0.13$} \\
\hline
\end{tabular}


Table 3. Cell growth inhibition (\%) of the normal cell (WI-38 human caucasian fibroblast-like fetal lung cell line) in the MTT assay after treatment with crude extract of four seaweeds for 24 hours and IC50 (concentration of extracts used = 0:1000 $\mu \mathrm{g} / \mathrm{mL}$ ).

\begin{tabular}{|c|c|c|c|c|}
\hline \multirow{3}{*}{$\begin{array}{l}\text { Concentration } \\
(\mu \mathrm{g} / \mathrm{mL})\end{array}$} & \multicolumn{4}{|c|}{ Cell growth inhibition (\%) } \\
\hline & $\begin{array}{c}\text { P. pavonica } \\
\text { (methanol extract) }\end{array}$ & $\begin{array}{c}\text { J. rubens } \\
\text { (methanol extract) }\end{array}$ & $\begin{array}{c}\text { T. atomaria } \\
\text { (Ethanol extract) }\end{array}$ & $\begin{array}{c}\text { C.elongata } \\
\text { (methanol extract) }\end{array}$ \\
\hline & \multicolumn{4}{|c|}{ After $24 \mathrm{hrs}$} \\
\hline 0 & 0 & 0 & 0 & 0 \\
\hline 10 & $11.3 \pm 4.0^{\circ}$ & $28.9 \pm 3.6^{\circ}$ & $12.6 \pm 7.8^{\infty}$ & $13.4 \pm 6.4^{\circ}$ \\
\hline 50 & $12.8 \pm 1.3^{\circ}$ & $34.0 \pm 4.8^{\circ}$ & $19.0 \pm 5.7^{\circ}$ & $34.4 \pm 5.6^{\circ}$ \\
\hline 100 & $18.0 \pm 2.0^{\circ}$ & $36.2 \pm 8.0^{\circ}$ & $42.7 \pm 7.1^{\circ}$ & $45.0 \pm 2.5^{\circ}$ \\
\hline 200 & $34.9 \pm 4.4^{\circ}$ & $50.8 \pm 3.7^{\oplus}$ & $44.1 \pm 2.5^{\circ}$ & $54.5 \pm 2.8^{\infty}$ \\
\hline 400 & $34.2 \pm 4.2^{\circ}$ & $58.3 \pm 4.1^{\circ}$ & $46.9 \pm 8.6^{\circ}$ & $54.2 \pm 0.7^{\circ}$ \\
\hline 600 & $33.6 \pm 3.6^{\circ}$ & $60.5 \pm 1.6^{\oplus}$ & $52.9 \pm 5.7^{\circledR}$ & $56.5 \pm 1.2^{\circ}$ \\
\hline 800 & $37.0 \pm 2.5^{\circ}$ & $61.3 \pm 0.61^{\circ}$ & $55.3 \pm 3.2^{\circ}$ & $59.7 \pm 3.6^{\circ}$ \\
\hline 1000 & $43.4 \pm 2.6^{\circ}$ & $62.6 \pm 5.0^{\circ}$ & $57.1 \pm 7.6^{\circ}$ & $63.9 \pm 2.8^{\circ}$ \\
\hline $\mathrm{IC}_{50}(\mu \mathrm{g} / \mathrm{mL})$ & 1164.9 & 422.7 & 630.7 & 460.3 \\
\hline
\end{tabular}

Data were represented as mean \pm SD. Difference between groups was considered statistically significant at $\mathrm{P}<0.05$. ${ }^{\circ}:$ Statistically significant vs. standard drug Cisplatin $(100 \mu \mathrm{g} / \mathrm{mL})$ after 24 hrs.

Table 4. Cell growth inhibition (\%) of the normal cell (WI-38 human caucasian fibroblast-like fetal lung cell line) in the MTT assay after treatment with standard drug Cisplatin for 24 hours and IC50 (concentration of drug used $=0: 100 \mu \mathrm{g} / \mathrm{mL}$ ).

\begin{tabular}{cc}
\hline & Cell growth inhibition $(\%)$ \\
\cline { 2 - 2 } Concentration $(\mu \mathrm{g} / \mathrm{mL})$ & Cisplatin \\
\cline { 2 - 2 } & After $24 \mathrm{hrs}$ \\
\hline 0 & 0 \\
10 & $32.8 \pm 7.5$ \\
20 & $55.0 \pm 27.8$ \\
40 & $65.8 \pm 13.7$ \\
80 & $70.4 \pm 7.2$ \\
100 & $80.2 \pm 15.3$ \\
IC50 $(\mu \mathrm{g} / \mathrm{mL})$ & $86.9 \pm 3.4$ \\
\hline
\end{tabular}

Data were represented as mean $\pm \mathrm{SD}$.

on the findings of the studies on seaweeds, many types of algae can avoid oxidative damage through scavenging free radicals and thus prevent the development of cancer cells (Athukorala et al., 2006). Some algae have long been used for cancer treatment in traditional Chinese herbal medicine (Yamamoto et al., 1984).

To define whether the studied seaweed extracts affect the proliferation of tumor cell, their effects on HeLa Cancer Cell Lines were investigated using MTT assay. The proliferation courses over 24 and 48 hrs after the addition of seaweed extracts in HeLa Cancer Cell Lines showed a direct relationship between the cell viability decrease and cell proliferation inhibition. All the tested seaweed extracts increased cell growth inhibition in HeLa Cancer Cell Lines in the dose and time-dependent manners (Table 5) compared to the standard drug Cisplatin (Table 6). These results revealed that the four seaweed extracts might influence tumor cell proliferation compared to normal cells. The cell growth inhibition increased by increasing the seaweed extracts concentration and incubation period. All the studied seaweed extracts give nearly equal cell growth inhibition over 24 and 48 hrs (Table 5). Compared with the Standard drug
Cisplatin, all concentrations of extracts possess anticancer activity against the HeLa Cancer Cell Lines. The higher cell growth inhibition and anticancer activity were detected with lower $\mathrm{IC}_{50}$ values. The $\mathrm{IC}_{50}$ of the methanol extract of J. rubens and $P$. pavonica after 24 and 48 hrs was the lowest, and it gave the highest cell growth inhibition compared to other seaweed extracts and standard drug Cisplatin, so methanol extract of $J$. rubens and $P$. pavonica become a promising candidate for anticancer activity (Table 5 and 6). These findings are in line with Ashwini et al. (2016), who observed that the chloroform and ethanol extracts of Gracilaria corticata recorded a greater anticancer activity against HeLa Cancer Cell Lines with an IC50 value of $341.82 \mu \mathrm{g} / \mathrm{mL}$ and $244.7 \mu \mathrm{g} / \mathrm{mL}$, respectively for 48hours. The methanol extract of $P$. pavonica, harvested from the Adriatic Sea, Montenegro, has cytotoxic activity against HeLa cell lines with IC50 values of $86.45 \mu \mathrm{g} / \mathrm{mL}$ after treatment for 72 hours (Stanojković et al., 2013). In addition, Corallina pilulifera ethanolic extracts displayed cytotoxic potency against the human cervical Hela adenocarcinoma cell line. The IC50 of the C. pilulifera ethanolic extracts was $250 \mu \mathrm{g} / \mathrm{mL}$ for 24 hours related to the HeLa cells. HeLa cell treatment with different concentrations of $C$. pilulifera ethanolic extracts caused induction of the apoptosis and growth inhibition in a dose-dependent manner (Kwon et al., 2007).

Many findings demonstrated a close relationship between algal anticancer potency and their contents of antioxidant compounds such as polyphenols, flavonoids, saponins, tannins, alkaloids, and fatty acids. Therefore, the cytotoxic potential of seaweeds via the inhibition of the proliferation of Human Cervical HeLa Cancer Cell Lines is likely to be related to their content of these compounds. Some flavonoids may also affect the development of hormones and prevent aromatase to avoid the proliferation of cancer cells, while the effect of polyphenolic compounds by xenobiotic-metabolizing enzymes that modify potential carcinogens' metabolic activation and inhibit cancer cells (Zhao et al., 2007). The polyphenols anticancer potential may be mediated by several anticancer mechanisms such as interaction with main enzymes in the cell cycle, cellular signaling pathways, 


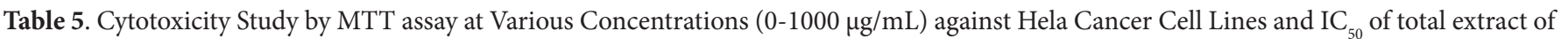
four seaweeds.

\begin{tabular}{|c|c|c|c|c|c|c|c|c|}
\hline \multirow{3}{*}{$\begin{array}{l}\text { Concentration } \\
(\mu \mathrm{g} / \mathrm{mL})\end{array}$} & \multicolumn{8}{|c|}{ Cell growth inhibition (\%) } \\
\hline & \multicolumn{2}{|c|}{ P. pavonica (Methanol extract) } & \multicolumn{2}{|c|}{ J. rubens (Methanol extract) } & \multicolumn{2}{|c|}{ T. atomaria (Ethanol extract) } & \multicolumn{2}{|c|}{ C. elongata (Methanol extract) } \\
\hline & After 24 hrs & After $48 \mathrm{hrs}$ & After $24 \mathrm{hrs}$ & After $48 \mathrm{hrs}$ & After $24 \mathrm{hrs}$ & After $48 \mathrm{hrs}$ & After $24 \mathrm{hrs}$ & After $48 \mathrm{hrs}$ \\
\hline Control & 0 & 0 & 0 & 0 & 0 & 0 & 0 & 0 \\
\hline 50 & $23.7 \pm 9.8^{*}$ & $46.9 \pm 4.0 €$ & $7.5 \pm 0.8$ & $49.7 \pm 14.1 €$ & $21.3 \pm 8.5$ & $43.6 \pm 7.4 €$ & $22.4 \pm 7.4^{*}$ & $40.8 \pm 8.0 €$ \\
\hline 100 & $28.0 \pm 5.0^{*}$ & $49.1 \pm 4.0 €$ & $9.1 \pm 5.1$ & $56.5 \pm 7.04 €$ & $20.5 \pm 7.9$ & $50.1 \pm 2.8 €$ & $24.9 \pm 10.1^{*}$ & $48.0 \pm 5.5 €$ \\
\hline 600 & $39.11 \pm 2.9^{*}$ & $96.5 \pm 0.2 €$ & $54.0 \pm 7.6^{*}$ & $98.0 \pm 0.37 €$ & $39.7 \pm 9.6^{*}$ & $71.4 \pm 5.0 €$ & $36.9 \pm 8.0^{*}$ & $78.8 \pm 4.4 €$ \\
\hline 800 & $43.7 \pm 7.0^{*}$ & $97.8 \pm 0.49 €$ & $55.1 \pm 9.4^{*}$ & $98.82 \pm 0.42 €$ & $40.7 \pm 5.2^{\star}$ & $94.4 \pm 5.8 €$ & $42.4 \pm 2.3^{*}$ & $98.2 \pm 0.4 €$ \\
\hline 1000 & $51.0 \pm 12.7^{*}$ & $98.4 \pm 0.79 €$ & $72.8 \pm 2.6^{*}$ & $99.5 \pm 0.18 €$ & $52.0 \pm 14.9^{*}$ & $98.2 \pm 1.1 €$ & $44.7 \pm 5.8^{*}$ & $99.4 \pm 0.3 €$ \\
\hline $\mathrm{IC50}(\mu \mathrm{g} / \mathrm{mL})$ & 964.4 & 145.3 & 630.5 & 37.9 & 955.8 & 189.5 & 1077.1 & 167.4 \\
\hline
\end{tabular}

Table 6. Cytotoxicity Study by MTT assay at Various Concentration $(0-100 \mu \mathrm{g} / \mathrm{mL})$ against Hela Cancer Cell Lines and $\mathrm{IC}_{50}$ of Standard drug (Cisplatin).

\begin{tabular}{ccc}
\hline \multirow{2}{*}{$\begin{array}{c}\text { Concentration } \\
(\mu \mathrm{g} / \mathrm{mL})\end{array}$} & \multicolumn{2}{c}{ Cell growth inhibition (\%) } \\
\cline { 2 - 3 } & \multicolumn{2}{c}{ Cisplatin } \\
\cline { 2 - 3 } Control & 0 & After $24 \mathrm{hrs}$ \\
5 & $7.1 \pm 3.0$ & $66.2 \pm 7.5 €$ \\
10 & $17.9 \pm 6.4^{*}$ & $68.2 \pm 7.8 €$ \\
20 & $32.1 \pm 4.6^{*}$ & $73.5 \pm 6.2 €$ \\
40 & $44.7 \pm 7.0^{*}$ & $80.0 \pm 8.9 €$ \\
80 & $55.4 \pm 7.9^{*}$ & $90.3 \pm 3.4 €$ \\
100 & $60.62 \pm 4.4^{*}$ & $94.7 \pm 1.7 €$ \\
$\mathrm{IC} 50(\mu \mathrm{g} / \mathrm{mL})$ & 69.6 & $\mathrm{ND}$ \\
\hline
\end{tabular}

$\overline{\text { Data were represented as mean } \pm \mathrm{SD} \text {. Difference between groups was considered }}$ statistically significant at $\mathrm{P}<0.05$. ${ }^{\star}$ Statistically significant vs. control after $24 \mathrm{hrs}$; ${ }^{€}$ Statistically significant vs. Control after $48 \mathrm{~h}$.

metastasis, and apoptosis (Kuttan et al., 2007; Lamoral-Theys et al., 2010). On the other hand, Alkaloids' cytotoxic behavior is attributed to microtubule interfering agents that may attach to beta tubulin, thus preventing the development of the mitotic spindle fiber essential for cell division (Solanki et al., 2008). In addition, saponins can protect cells from being cancerous, improve immune function, delay the growth of cancer cells, reduce the development of cancer-related hormones, serve as antioxidants, and counter viruses (Shree et al., 2019). Fatty acids abound in algae species and have diverse biological activities such as anticancer activities (Miccadei et al., 2016) and antiinflammatory activities (Poland et al., 2016).

\section{Conclusion}

The four brown and red seaweeds Padina pavonica, Taonia atomaria, Jania rubens, and Corallina elongata collected from Abu Qir Bay, Alexandria, Egypt, are rich in secondary metabolites (phenolics, flavonoids, saponins, tannins, and alkaloids). Therefore, they are considered promising natural candidates for antioxidant, antidiabetic, anti-inflammatory, and anticancer therapy. In the future, it is recommended to study the bioactive compounds responsible for the activities and expand the applied research on such extracts of the studied species for further therapeutic, medicinal uses and in vivo studies.

\section{Conflict of interest}

The authors declare that they have no known competing financial interests or personal relationships that could have influenced the work reported in this paper.

\section{Author contributions}

Mostafa El-Sheekh: Conceptualization, Investigation, Writing - review \& editing. Shimaa El Shafay: Writing, Methodology, Investigation. Eman Bases: Investigation, Methodology, analyses, and Writing. Rania El-Shenody: Methodology, Investigation.

\section{Acknowledgements}

We would like to thank Dr. Mona M. Ismail (Assistant Professor of Phycology National Institute of Oceanography and Fisheries, Alexandria, Egypt) for her help in identifying the algae used in this research paper.

\section{References}

Adwas, A., Elsayed, A., \& Azab, A. (2019). Oxidative stress and antioxidant mechanisms in human body. Journal of Applied Biotechnology \& Bioengineering, 6(1), 43-47.

Al-Araby, S. Q., Rahman, M. A., Chowdhury, M. A. H., Das, R. R., Chowdhury, T. A., Hasan, C. M. M., Afroze, M., Hashem, M. A., Hajjar, D., Alelwani, W., Makki, A. A., \& Haque, M. A. (2020). Padina tenuis (marine alga) attenuates oxidative stress and streptozotocin-induced type 2 diabetic indices in Wistar albino rats. South African Journal of Botany, 128, 87-100. http://dx.doi.org/10.1016/j.sajb.2019.09.007.

Aleem, A. A. (1993). The marine Algae of Alexandria, Egypt (pp. 1-55). Alexandria: Privately Published. 
Alghazeer, R., Enaeli, M., \& Howell, N. K. (2016). Anticancer and antioxidant activities of some algae from western Libyan coast. Nature and Science, 10(7), 232-246.

Ananthi, S., Raghavendran, H. R. B., Sunil, A. G., Gayathri, V., Ramakrishnan, G., \& Vasanthi, H. R. (2010). In vitro antioxidant and in vivo anti-inflammatory potential of crude polysaccharide from Turbinaria ornata (Marine Brown Alga). Food and Chemical Toxicology, 48(1), 187-192. http://dx.doi.org/10.1016/j.fct.2009.09.036. PMid:19799956.

Apostolidis, E., Karayannakidis, P. D., Kwon, Y.-I., Lee, C. M., \& Seeram, N. P. (2011). Seasonal variation of phenolic antioxidant-mediated a-glucosidase inhibition of Ascophyllum nodosum. Plant Foods for Human Nutrition, 66(4), 313-319. http://dx.doi.org/10.1007/ s11130-011-0250-4. PMid:21842257.

Ashwini, S., Babut, S., \& Saritha, M. S. (2016). Seaweed extracts exhibit anticancer activity against HeLa cell lines. Int J Curr Pharm Res, 9(1), 114-117. http://dx.doi.org/10.22159/ijcpr.2017v9i1.16632.

Athukorala, Y., Kim, K.-N., \& Jeon, Y.-J. (2006). Antiproliferative and antioxidant properties of an enzymatic hydrolysate from brown alga, Ecklonia cava. Food and Chemical Toxicology, 44(7), 10651074. http://dx.doi.org/10.1016/j.fct.2006.01.011. PMid:16516367.

Azeem, A. K., Dilip, C., Prasanth, S. S., Shahima, V. J. H., Sajeev, K., \& Naseera, C. (2010). Anti-inflammatory activity of the glandular extracts of Thunnus alalunga. Asian Pacific Journal of Tropical Medicine, 3(10), 794-796. http://dx.doi.org/10.1016/S1995-7645(10)60190-3.

Boonchum, W., Peerapornpisal, Y., Kanjanapothi, D., Pekkoh, J., Pumas, C., Jamjai, U., Amornlerdpison, D., Noiraksa, T., \& Vacharapiyasophon, P. (2011). Antioxidant activity of some seaweed from the Gulf of Thailand. International Journal of Agriculture and Biology, 13(1)

Burton, G. W., \& Ingold, K. U. (1999). Mechanism of antioxidant action: preventive and chain breaking antioxidants. In J. Miquel (Ed.), CRC handbook offree radicals and antioxidants in biomedicine (Chap. 10, pp. 29-43). Boca Raton: CRC Press.

Chaitanya, R., Sandhya, S., David, B., Vinod, K. R., \& Murali, S. (2011). HRBC membrane stabilizing property of roor, stem and leaf of glochidion velutinum. International Journal of Research in Pharmaceutical and Biomedical Sciences, 2(1), 256-259.

Chang, C.-C., Yang, M.-H., Wen, H.-M., \& Chern, J.-C. (2002). Estimation of total flavonoid content in propolis by two complementary colorimetric methods. Yao Wu Shi Pin Fen Xi, 10(3). http://dx.doi. org/10.38212/2224-6614.2748.

Chew, Y. L., Lim, Y. Y., Omar, M., \& Khoo, K. S. (2008). Antioxidant activity of three edible seaweeds from two areas in South East Asia. Lebensmittel-Wissenschaft + Technologie, 41(6), 1067-1072. http:// dx.doi.org/10.1016/j.lwt.2007.06.013.

Cho, M., Kang, I.-J., Won, M.-H., Lee, H.-S., \& You, S. (2010). The antioxidant properties of ethanol extracts and their solvent-partitioned fractions from various green seaweeds. Journal of Medicinal Food, 13(5), 1232-1239. http://dx.doi.org/10.1089/jmf.2010.1124. PMid:20828323.

Dang, T. T., Bowyer, M. C., Van Altena, I. A., \& Scarlett, C. J. (2018). Comparison of chemical profile and antioxidant properties of the brown algae. International Journal of Food Science \& Technology, 53(1), 174-181. http://dx.doi.org/10.1111/ijfs.13571.

Deyab, M., Elkatony, T., \& Ward, F. (2016). Qualitative and quantitative analysis of phytochemical studies on brown seaweed, Dictyota dichotoma. International Journal of Engineering Development and Research, 4(2), 2321-2330.

Duan, X.-J., Zhang, W.-W., Li, X.-M., \& Wang, B.-G. (2006). Evaluation of antioxidant property of extract and fractions obtained from a red alga, Polysiphonia urceolata. Food Chemistry, 95(1), 37-43. http:// dx.doi.org/10.1016/j.foodchem.2004.12.015.

El-Shaibany, A., AL-Habori, M., Al-Maqtari, T., \& Al-Mahbashi, H. (2020). The Yemeni brown algae Dictyota dichotoma exhibit high in vitro anticancer activity independent of its antioxidant capability. BioMed Research International, 2020, 2425693. http://dx.doi. org/10.1155/2020/2425693.

El-Sheekh, M. M., El-Shenody, R. A. E. K., Bases, E. A., \& El Shafay, S. M. (2020). Comparative assessment of antioxidant activity and biochemical composition of four seaweeds, Rocky Bay of Abu Qir in Alexandria, Egypt. Food Science and Technology, 41(1, Suppl 1), 29-40. http://dx.doi.org/10.1590/fst.06120.

El-Shenody, R. A., Ashour, M., \& Ghobara, M. M. E. (2019). Evaluating the chemical composition and antioxidant activity of three Egyptian seaweeds: Dictyota dichotoma, Turbinaria decurrens, and Laurencia obtusa. Brazilian Journal of Food Technology, 22, e2018203. http:// dx.doi.org/10.1590/1981-6723.20318.

European Community. (2000). Reference method of tannins dosages. Official Journal of the European Communities (pp. 18-20), L 197.

Fauzi, A., Lamma, S., \& Ruslin, M. (2018). Total tannin levels analysis of brown algae (sargassum sp and padina sp) to prevent blood loss in a surgery. Journal of Dentomaxillofacial Science, 3(1), 37-40. http:// dx.doi.org/10.15562/jdmfs.v3i1.621.

Feroz, B. (2018). Saponins from marine macroalgae: a review. Journal of Marine Science: Research \& Development, 8(04), 255. http://dx.doi. org/10.4172/2155-9910.1000255.

Ferrali, M., Signorini, C., Ciccoli, L., \& Comporti, M. (1992). Iron release and membrane damage in erythrocytes exposed to oxidizing agents, phenylhydrazine, divicine and isouramil. The Biochemical Journal, 285(1), 295-301. http://dx.doi.org/10.1042/bj2850295. PMid:1637315.

Ganesan, P., Kumar, C. S., \& Bhaskar, N. (2008). Antioxidant properties of methanol extract and its solvent fractions obtained from selected Indian red seaweeds. Bioresource Technology, 99(8), 2717-2723. http://dx.doi.org/10.1016/j.biortech.2007.07.005. PMid:17706415.

Guiry, M. D., \& Guiry, G. M. (2019). AlgaeBase. Galway: National University of Ireland. Retrieved from https://www.algaebase.org/

Güven, K. C., Percot, A., \& Sezik, E. (2010). Alkaloids in marine algae. Marine Drugs, 8(2), 269-284. http://dx.doi.org/10.3390/md8020269. PMid:20390105.

Harbone, J. B. (1973). Phenolic compounds. In J. B. Harborne (Ed.), Phytochemical methods: a guide to modern techniques of plant analysis (pp. 271-280). New Delhi: Springer.

Harborne, J. B. (1984). Phytochemical methods (pp. 100-117). New York: Chapman \& Hall.

Hardmann, J. A., Limbard, L. E., \& Goodmann, A. (1998). Pharmacological basis of therapeutics. New York: McGraw Hill.

Hayes, M. (2015). Seaweeds: a nutraceutical and health food. In B. K. Tiwari \& D. J. Troy (Eds.), Seaweed sustainability: food and nonfood applications (pp. 365-387). Amsterdam: Elsevier. http://dx.doi. org/10.1016/B978-0-12-418697-2.00014-3.

Hess, S. M., \& Milong, R. C. (1972). Inflammation mechanism and control (pp. 1-2). New York: Academic Press.

Hiai, S., Oura, H., Odaka, Y., \& Nakajima, T. (1975). A colorimetric estimation of ginseng saponins. Planta Medica, 28(4), 363-369. http:// dx.doi.org/10.1055/s-0028-1097871. PMid:1208686.

Husni, A., Pawestri, S., \& Isnansetyo, A. (2016). Blood glucose level and lipid profile of alloxan-induced diabetic rats treated with $\mathrm{Na}-$ alginate from seaweed Turbinaria ornata (Turner) J. agardh. Jurnal Teknologi, 78(4-2), 4-2. http://dx.doi.org/10.11113/jt.v78.8145. 
Ibrahim, E. A., Aly, H. F., Baker, D. H. A., Mahmoud, K., \& El-Baz, F. K. (2016). Marine algal sterol hydrocarbon with anti-inflammatory, anticancer and anti-oxidant properties. International Journal of Pharma and Bio Sciences, 7, 392-398.

Ismail, G. A., Gheda, S. F., Abo-Shady, A. M., \& Abdel-Karim, O. H. (2020). In vitro potential activity of some seaweeds as antioxidants and inhibitors of diabetic enzymes. Food Science and Technology, 40(3), 681-691. http://dx.doi.org/10.1590/fst.15619.

Jha, B., Reddy, C. R. K., Thakur, M. C., \& Rao, M. U. (2009). Seaweeds of India: the diversity and distribution of seaweeds of gujarat coast (Vol. 3). Dordrecht: Springer Science \& Business Media. http:// dx.doi.org/10.1007/978-90-481-2488-6.

Jia, R.-B., Wu, J., Li, Z.-R., Ou, Z.-R., Zhu, Q., Sun, B., Lin, L., \& Zhao, M. (2020). Comparison of physicochemical properties and antidiabetic effects of polysaccharides extracted from three seaweed species. International Journal of Biological Macromolecules, 149, 81-92. http://dx.doi.org/10.1016/j.ijbiomac.2020.01.111. PMid:31945436.

Kanaan H., \& Belous, O. (2016). Marine algae of the Lebanese coast. New York: Nova Science Publisher.

Kohen, R., \& Nyska, A. (2002). Oxidation of biological systems: oxidative stress phenomena, antioxidants, redox reactions, and methods for their quantification. Toxicologic Pathology, 30(6), 620-650. http:// dx.doi.org/10.1080/01926230290166724. PMid:12512863.

Kohler, N., Sun, C., Wang, J., \& Zhang, M. (2005). Methotrexate-modified superparamagnetic nanoparticles and their intracellular uptake into human cancer cells. Langmuir, 21(19), 8858-8864. http://dx.doi. org/10.1021/la0503451. PMid:16142971.

Kolodziej, H., \& Kiderlen, A. F. (2005). Antileishmanial activity and immune modulatory effects of tannins and related compounds on Leishmania parasitised RAW 264.7 cells. Phytochemistry, 66(17), 2056-2071. http://dx.doi.org/10.1016/j.phytochem.2005.01.011. PMid:16153409.

Kuda, T., Kunii, T., Goto, H., Suzuki, T., \& Yano, T. (2007). Varieties of antioxidant and antibacterial properties of Ecklonia stolonifera and Ecklonia kurome products harvested and processed in the Noto peninsula, Japan. Food Chemistry, 103(3), 900-905. http://dx.doi. org/10.1016/j.foodchem.2006.09.042. PMid:26065751.

Kumbhar, R. D., Rode, S. P., \& Sabale, A. B. (2014). Phycochemical screening of seaweeds from Sindhudurg district of Maharashtra. International Journal of Pharmaceutical Sciences Review and Research, 29, 77-81.

Kuttan, G., Kumar, K. B. H., Guruvayoorappan, C., \& Kuttan, R. (2007). Antitumor, anti-invasion, and antimetastatic effects of curcumin. In B. B. Aggarwal, Y.-J. Surh \& S. Shishodia (Eds.), The molecular targets and therapeutic uses of curcumin in health and disease (pp. 173-184). Dordrecht: Springer. http://dx.doi.org/10.1007/978-0387-46401-5_6.

Kwon, H.-J., Bae, S.-Y., Kim, K.-H., Han, C.-H., Cho, S.-H., Nam, S.-W., Choi, Y. H., \& Kim, B.-W. (2007). Induction of apoptosis in HeLa cells by ethanolic extract of Corallina pilulifera. Food Chemistry, 104(1), 196-201. http://dx.doi.org/10.1016/j.foodchem.2006.11.031. PMid:26054281.

Lamoral-Theys, D., Pottier, L., Dufrasne, F., Neve, J., Dubois, J., Kornienko, A., Kiss, R., \& Ingrassia, L. (2010). Natural polyphenols that display anticancer properties through inhibition of kinase activity. Current Medicinal Chemistry, 17(9), 812-825. http://dx.doi. org/10.2174/092986710790712183. PMid:20156174.

Lee, S.-H., Yong-Li, Karadeniz, F., Kim, M.-M., \& Kim, S.-K. (2009). $\alpha$-Glucosidase and $\alpha$-amylase inhibitory activities of phloroglucinal derivatives from edible marine brown alga, Ecklonia cava. Journal of the Science of Food and Agriculture, 89(9), 1552-1558. http://dx.doi. org/10.1002/jsfa.3623.

Li, Y.-X., Wijesekara, I., Li, Y., \& Kim, S.-K. (2011). Phlorotannins as bioactive agents from brown algae. Process Biochemistry, 46(12), 2219-2224. http://dx.doi.org/10.1016/j.procbio.2011.09.015.

Mehdinezhad, N., Ghannadi, A., \& Yegdaneh, A. (2016). Phytochemical and biological evaluation of some Sargassum species from Persian Gulf. Research in Pharmaceutical Sciences, 11(3), 243-249. PMid:27499794.

Miccadei, S., Masella, R., Mileo, A. M., \& Gessani, S. (2016). w3 Polyunsaturated fatty acids as immunomodulators in colorectal cancer: new potential role in adjuvant therapies. Frontiers in Immunology, 7 , 486. http://dx.doi.org/10.3389/fimmu.2016.00486. PMid:27895640.

Mohamed, S., Hashim, S. N., \& Rahman, H. A. (2012). Seaweeds: a sustainable functional food for complementary and alternative therapy. Trends in Food Science \& Technology, 23(2), 83-96. http:// dx.doi.org/10.1016/j.tifs.2011.09.001.

Mohy El-Din, S. M., \& El-Ahwany, A. M. D. (2016). Bioactivity and phytochemical constituents of marine red seaweeds (Jania rubens, Corallina mediterranea and Pterocladia capillacea). Journal of Taibah University for Science, 10(4), 471-484. http://dx.doi.org/10.1016/j. jtusci.2015.06.004.

Morobe, I. C., Mthethwa, N. S., Bisi-Johnson, M. A., Vasaikar, S. D., Obi, C. L., Oyedeji, A. O., et al (2012). Cytotoxic effects and safety profiles of extracts of active medicinal plants from South Africa. Journal of Microbiology Research, 2(6), 176-182. http://dx.doi. org/10.5923/j.microbiology.20120206.04.

Mounnissamy, V. M., Kavimani, S., Balu, V., \& Quine, S. D. (2007). Evaluation of anti-inflammatory and membrane stabilizing properties of ethanol extract of Cansjera rheedii J.Gmelin (Opiliaceae)). Iranian Journal of Pharmacology and Therapeutics, 6(2), 230-235.

Okolie, C. L., Mason, B., \& Critchley, A. T. (2018). Seaweeds as a source of proteins for use in pharmaceuticals and high-value applications. In M. Hayes (Ed.), Novel proteins for food, pharmaceuticals and agriculture: sources, applications and advances (1st ed., Chap. 11). Hoboken: Wiley. http://dx.doi.org/10.1002/9781119385332.ch11.

Oueslati, S., Ksouri, R., Falleh, H., Pichette, A., Abdelly, C., \& Legault, J. (2012). Phenolic content, antioxidant, anti-inflammatory and anticancer activities of the edible halophyte Suaeda fruticosa Forssk. Food Chemistry, 132(2), 943-947. http://dx.doi.org/10.1016/j. foodchem.2011.11.072.

Pirian, K., Moein, S., Sohrabipour, J., Rabiei, R., \& Blomster, J. (2017). Antidiabetic and antioxidant activities of brown and red macroalgae from the Persian Gulf. Journal of Applied Phycology, 29(6), 31513159. http://dx.doi.org/10.1007/s10811-017-1152-0.

Poland, M., Ten Klooster, J. P., Wang, Z., Pieters, R., Boekschoten, M., Witkamp, R., \& Meijerink, J. (2016). Docosahexaenoyl serotonin, an endogenously formed n-3 fatty acid-serotonin conjugate has antiinflammatory properties by attenuating IL-23-IL-17 signaling in macrophages. Biochimica et Biophysica Acta, 1861(12), 2020-2028. http://dx.doi.org/10.1016/j.bbalip.2016.09.012. PMid:27663185.

Pramitha, V. S., \& Sree Kumari, N. (2016). Anti-inflammatory, antioxidant, phytochemical and GC-MS analysis of marine brown macroalga, Sargassum wighti. International Journal of Pharmaceutical, Chemical and Biological Sciences, 6(1), 7-15.

Qasem, J. R. (2015). Prospects of wild medicinal and industrial plants of saline habitats in the Jordan valley. Pakistan Journal of Botany, 47(2), 551-570.

Rajkumar, G., \& Bhavan, P. S. (2017). Phytochemical characterization of the marine brown alga Turbinaria ornata. Research Journal of Chemistry and Environment, 21(3), 54-63. 
Rani, A. A., Punitha, S. M. J., \& Rema, M. (2014). Anti-inflammatory activity of flower extract of Cassia auriculata: an in-vitro study. International Research Journal of Pharmaceutical and Applied Sciences, 4, 57-60.

Ross, J. A., \& Kasum, C. M. (2002). Dietary flavonoids: bioavailability, metabolic effects, and safety. Annual Review of Nutrition, 22(1), 19-34. http://dx.doi.org/10.1146/annurev.nutr.22.111401.144957. PMid:12055336.

Sadique, J., Al-Rqobah, W. A., Bughaith, M. F., \& El-Gindy, A. R. (1989). The bio-activity of certain medicinal plants on the stabilization of RBC membrane system. Fitoterapia, 60, 525-532.

Sakat, S., Juvekar, A. R., \& Gambhire, M. N. (2010). In vitro antioxidant and anti-inflammatory activity of methanol extract of Oxalis corniculata Linn. International Journal of Pharmacy and Pharmaceutical Sciences, 2(1), 146-155.

Santos-Sánchez, N. F., Salas-Coronado, R., Villanueva-Cañongo, C., \& Hernández-Carlos, B. (2019). Antioxidant compounds and their antioxidant mechanism. In E. Shalaby (Ed.), Antioxidants. London: IntechOpen. http://dx.doi.org/10.5772/intechopen.85270.

Shannon, E., \& Abu-Ghannam, N. (2019). Seaweeds as nutraceuticals for health and nutrition. Phycologia, 58(5), 563-577. http://dx.doi. org/10.1080/00318884.2019.1640533.

Shree, T. J., Poompavai, S., Begum, S., Gowrisree, V., \& Hemalatha, S. (2019). Cancer-fighting phytochemicals: another look. Journal of Nanomedicine \& Biotherapeutic Discovery, 8, 162.

Singh, N., \& Rajini, P. S. (2004). Free radical scavenging activity of an aqueous extract of potato peel. Food Chemistry, 85(4), 611-616. http://dx.doi.org/10.1016/j.foodchem.2003.07.003.

Solanki, R., Khanna, M., \& Lal, R. (2008). Bioactive compounds from marine actinomycetes. Indian Journal of Microbiology, 48(4), 410431. http://dx.doi.org/10.1007/s12088-008-0052-z. PMid:23100742.

Stanojković, T. P., Šavikin, K., Zdunić, G., Kljajić, Z., Grozdanić, N., \& Antić, J. (2013). In vitro antitumoral activities of Padina pavonia on human cervix and breast cancer cell lines. Journal of Medicinal Plants Research, 7, 419-424.

Stirk, W. A., Reinecke, D. L., \& van Staden, J. (2007). Seasonal variation in antifungal, antibacterial and acetylcholinesterase activity in seven South African seaweeds. Journal of Applied Phycology, 19(3), 271276. http://dx.doi.org/10.1007/s10811-006-9134-7.

Stojkovic, D., Smiljkovic, M., Ciric, A., Glamoclija, J., Van Griensven, L., Ferreira, I. C. F. R., \& Sokovic, M. (2019). An insight into antidiabetic properties of six medicinal and edible mushrooms: inhibition of $\alpha$-amylase and $\alpha$-glucosidase linked to type- 2 diabetes. South African Journal of Botany, 120, 100-103. http://dx.doi.org/10.1016/j. sajb.2018.01.007.

Subramaniam, D., Hanna, L. E., Maheshkumar, K., Ponmurugan, K., Al-Dhabi, N. A., \& Murugan, P. (2020). Immune stimulatory and antiHIV-1 potential of extracts derived from marine brown algae Padina tetrastromatica. Journal of Complementary \& Integrative Medicine, 17(2). http://dx.doi.org/10.1515/jcim-2019-0071. PMid:31990663.

Taga, M. S., Miller, E. E., \& Pratt, D. E. (1984). Chia seeds as a source of natural lipid antioxidants. Journal of the American Oil Chemists' Society, 61(5), 928-931. http://dx.doi.org/10.1007/BF02542169.

Unnikrishnan, P. S., Suthindhiran, K., \& Jayasri, M. A. (2015). Antidiabetic potential of marine algae by inhibiting key metabolic enzymes.
Frontiers in Life Science, 8(2), 148-159. http://dx.doi.org/10.1080/ 21553769.2015 .1005244$.

Van Caneghem, P. (1972). Influence of some hydrosoluble substances with vitamin $P$ activity on the fragility of lysosomes in vitro. Biochemical Pharmacology, 21(11), 1543-1548. http://dx.doi.org/10.1016/00062952(72)90303-6. PMid:4630452.

Vega, J., Álvarez-Gómez, F., Güenaga, L., Figueroa, F. L., \& GómezPinchetti, J. L. (2020). Antioxidant activity of extracts from marine macroalgae, wild-collected and cultivated, in an integrated multitrophic aquaculture system. Aquaculture, 522, 735088. http://dx.doi. org/10.1016/j.aquaculture.2020.735088.

Wang, L., Park, Y.-J., Jeon, Y.-J., \& Ryu, B. (2018). Bioactivities of the edible brown seaweed, Undaria pinnatifida: a review. Aquaculture, 495, 873-880. http://dx.doi.org/10.1016/j.aquaculture.2018.06.079.

Williams, R. J., Spencer, J. P. E., \& Rice-Evans, C. (2004). Flavonoids: antioxidants or signalling molecules? Free Radical Biology \& Medicine, 36(7), 838-849. http://dx.doi.org/10.1016/j.freeradbiomed.2004.01.001. PMid:15019969.

Wu, X. J., \& Hansen, C. (2008). Antioxidant capacity, phenolic content, and polysaccharide content of Lentinus edodes grown in whey permeate-based submerged culture. Journal of Food Science, 73(1), M1-M8. http://dx.doi.org/10.1111/j.1750-3841.2007.00595.x. PMid:18211355.

Yamamoto, I., Takahashi, M., Tamura, E., Maruyama, H., \& Mori, H. (1984). Antitumor activity of edible marine algae: effect of crude fucoidan fractions prepared from edible brown seaweeds against L-1210 leukemia. In Eleventh International Seaweed Symposium (pp. 145-148). Switzerland: Springer. http://dx.doi.org/10.1007/978-94009-6560-7_22.

Yang, H.-W., Fernando, K. H. N., Oh, J.-Y., Li, X., Jeon, Y.-J., \& Ryu, B. (2019). Anti-obesity and anti-diabetic effects of Ishige okamurae. Marine Drugs, 17(4), 202. http://dx.doi.org/10.3390/md17040202. PMid:30934943.

Yen, G.-C., \& Chen, H.-Y. (1995). Antioxidant activity of various tea extracts in relation to their antimutagenicity. Journal of Agricultural and Food Chemistry, 43(1), 27-32. http://dx.doi.org/10.1021/jf00049a007.

Yu, Y., Wang, L., Fu, X., Wang, L., Fu, X., Yang, M., Han, Z., Mou, H., \& Jeon, Y.-J. (2019). Anti-oxidant and anti-inflammatory activities of ultrasonic-assistant extracted polyphenol-rich compounds from Sargassum muticum. Journal of Oceanology and Limnology, 37(3), 836-847. http://dx.doi.org/10.1007/s00343-019-8138-5.

Zandi, K., Tajbakhsh, S., Nabipour, I., Rastian, Z., Yousefi, F., Sharafian, S., \& Sartavi, K. (2010). In vitro antitumor activity of Gracilaria corticata (a red alga) against Jurkat and molt- 4 human cancer cell lines. African Journal of Biotechnology, 9(40), 6787-6790.

Zhao, M., Yang, B., Wang, J., Liu, Y., Yu, L., \& Jiang, Y. (2007). Immunomodulatory and anticancer activities of flavonoids extracted from litchi (Litchi chinensis Sonn.) pericarp. International Immunopharmacology, 7(2), 162-166. http://dx.doi.org/10.1016/j. intimp.2006.09.003. PMid:17178382.

Zucchi, M. R., \& Necchi, O. Jr. (2001). Effects of temperature, irradiance and photoperiod on growth and pigment content in some freshwater red algae in culture. Phycological Research, 49(2), 103-114. http:// dx.doi.org/10.1111/j.1440-1835.2001.tb00240.x. 